\title{
Identification and Evaluation of Sources of Resistance to Stem Rust Race Ug99 in Wheat
}

Peter N. Njau, Kenyan Agricultural Research Institute, (KARI)-Njoro, P.O. Njoro, Kenya; Yue Jin, United States Department of Agriculture-Agricultural Research Service, Cereal Disease Laboratory, University of Minnesota, St. Paul 55108; Julio Huerta-Espino, Campo Experimental Valle de México INIFAP, Apdo. Postal 10, 56230, Chapingo, Edo de México, México; Beat Keller, University of Zurich, Institute of Plant Biology Zollikerstrasse, 107, 8008 Zurich; and Ravi P. Singh, International Maize and Wheat Improvement Center (CIMMYT), Apdo. Postal 6-641, 06600, Mexico, DF

\begin{abstract}
Njau, P. N., Jin, Y., Huerta-Espino, J., Keller, B., and Singh, R. P. 2010. Identification and evaluation of sources of resistance to stem rust race Ug99 in wheat. Plant Dis. 94:413-419.

The race Ug99 of Puccinia graminis f. sp. tritici causing stem rust disease of wheat was initially identified in Uganda in 1998. It was designated as TTKSK based on the North American nomenclature and has caused periodic losses to wheat crops in East Africa. Ug99 has recently moved out of Africa to Yemen and West Asia. The most effective approach to prevent losses from stem rust is through the deployment of resistant cultivars. More effective sources of resistance need to be identified and incorporated in the existing commercial cultivars. The first Stem Rust Resistance Screening Nursery (1stSRRSN) assembled by the International Maize and Wheat Improvement Center (CIMMYT) consisted of elite and advanced CIMMYT bread wheat lines and was evaluated for resistance to Ug99 in Njoro, Kenya for four consecutive seasons (2005 to 2007). Seedling reactions were determined in the greenhouse at the Cereal Disease Laboratory, St. Paul, MN. Two race-specific genes, Sr24 and Sr25, were found to confer resistance to Ug99, although Sr24 became ineffective to a mutant race of Ug99, TTKST, in 2007. Three previously uncharacterized genes, one each from synthetic wheat, Chinese germplasm, and other genetic backgrounds, were detected. Although $30 \%$ of the screened lines were susceptible in the seedling stage, these lines displayed various levels of adult plant resistance (APR) in the field tests. Presence of the APR gene $S r 2$, identified based on the pseudo-black chaff phenotype on glumes and darkened internode, was common in wheat lines with APR. The information on the resistance identified in the 1stSRRSN constitutes an important source for breeding wheat for durable resistance.
\end{abstract}

Stem or black rust, caused by Puccinia graminis Pers. f. sp. tritici, has historically caused severe losses to wheat (Triticum aestivum L.) production worldwide. Its control for over 30 years through the use of genetic resistance is a remarkable success story. However, in 1998, high susceptibility of International Maize and Wheat Improvement Center (CIMMYT) germplasm was noted in Uganda (9), and an increase in stem rust incidence and severity was observed in Kenya in 2003.

The causal race, commonly known as Ug99 and designated as TTKSK based on the North American nomenclature $(2,19)$, carries virulence for several stem rust resistance genes commonly present in wheat germplasm. Characterization of virulence in the $P$. graminis f. sp. tritici populations and germplasm screening were simultane-

Corresponding author: P. N. Njau

E-mail: njaupnn@yahoo.com

Accepted for publication 30 November 2009.

doi:10.1094/PDIS-94-4-0413

(C) 2010 The American Phytopathological Society ously initiated in Kenya and Ethiopia in 2005. All isolates collected from Kenyan fields in 2004 and 2005 fitted the designation of TTKSK $(2,3)$.

Resistance genes that conferred low reactions to race TTKSK in seedling tests and in the field nursery at Njoro include Sr13, -22, -24, -25, -26, -27, -28, -32, -33, $-35,-36,-37,-39,-40,-44$, and - Tmp (4). Among the effective genes, $S r 22,-24,-25$, $-26,-36$, and -Tmp may have some immediate value (15). The other genes are either located in large alien chromosome segments, requiring a size reduction of the alien segment, or have lacked durability (15). CIMMYT triticale lines, which often carry $\mathrm{Sr} 27$ or $\mathrm{SrSatu}$, were highly resistant in the field at Njoro. Although Sr36 confers resistance to Ug99, another race in the region caused an epidemic on cv. Enkoy, which carries Sr36, in 1994 and subsequent years (15). Furthermore, it was found that both $\mathrm{Sr} 24$ and Sr36 which had shown resistance to $\mathrm{Ug} 99$ are no longer effective to new variants of $\operatorname{Ug} 99(2,5)$, although they are still very resistant to other important races in other parts of the world. Certain hexaploid synthetic ( $T$. turgidum $\times$ Aegilops tauschii) wheat- derived advanced lines and some lines with certain Chinese cultivars such as Shanghai no. 7 as parents have also shown adequate levels of resistance. However, the genetic basis of resistance is not known $(15,17)$.

Resistance gene $\mathrm{Sr} 2$ derived from cv. Hope and additional, unknown minor genes, commonly known as the " $\mathrm{Sr} 2 \mathrm{com}$ plex" $(7,10,13,14)$, provided the foundation for durable resistance to stem rust in germplasm from spring wheat of the Northern Great Plains in the United States, Prairie Provinces of Canada, Sydney University in Australia, and the spring wheat germplasm developed by Dr. N. E. Borlaug as part of a program sponsored by the Mexican Government and the Rockefeller Foundation $(7,10)$. Cv. Yaqui 50, released in Mexico during the 1950s, and other Sr2carrying wheat lines released since then, had stabilized the stem rust situation in Mexico and many other countries where modern semidwarf wheat cultivars were adopted. Singh et al. (15) reported that changes in stem rust races have not been observed in Mexico for almost 40 years and natural infections are nonexistent. Another Sr2-carrying cultivar, Sonalika, released in the mid-1960s in the Indian subcontinent and subsequently grown on millions of hectares, remained resistant to stem rust. When present alone, the $S r 2$ gene confers slow rusting that is not adequate under heavy disease pressure but does provide adequate resistance in combination with other genes. As has been done with leaf rust and yellow rust (16), Singh et al. (14) indicated that adequate levels of multigenic resistance to stem rust can be achieved by accumulating approximately four to five minor genes.

Race-specific stem rust resistance genes can obviously be overcome by new pathotypes relatively rapidly. McIntosh (7) describes cereal rusts as "social" diseases because the individual farmer is subject to airborne spores from areas beyond the farm and part of any inoculum produced on one farm is dispersed to others. Therefore, control of rust diseases must be addressed at the community level, preferably through the widespread use of resistant cultivars. Although several alien genes will provide resistance to $\mathrm{Ug} 99$ and its variants, 
the long-term strategy should focus on adult plant resistance (APR). One of the approaches to enhance the resistance conferred by the $S r 2$ gene is combining it with three or four additional minor genes to once again achieve durable resistance. The objective of our study was to identify various sources of race-specific resistance and APR to race Ug99 of the stem rust pathogen in CIMMYT-derived wheat germplasm.

\section{MATERIALS AND METHODS}

The origin of the 1st Stem Rust Resistance Screening Nursery. In 2005, about 2,000 advanced breeding materials and elite wheat germplasm were evaluated for resistance to race $\mathrm{Ug} 99$ of the wheat stem rust pathogen at the Wheat Research Station of Kenyan Agricultural Research Institute, Njoro, Kenya. Based on disease severity and infection responses of the screened lines, the 1st Stem Rust Resistance Screening Nursery (1stSRRSN) was assembled (17). This nursery comprised 103 wheat lines that scored less than 20MS (20\% disease severity with a moderately susceptible response) in the field whereas, at the same time, the susceptible genotypes and checks scored between $80 \mathrm{~S}$ and 100S ( 80 and $100 \%$ disease severity with a susceptible response).

Evaluation of seedling infection types. The 103 lines of the 1stSRRSN were evaluated in the greenhouse at St. Paul, MN using isolate 04KEN156 of $P$. graminis f. sp. tritici collected in Kenya in 2004. This isolate was identified as race TTKSK $(2,19)$ based on the 20 differentials in the $P$. graminis f. sp. tritici differential set of North America $(2,11,12)$. The procedure of inoculating seedling plants and disease assessment were as described previously (4). Infection types (ITs), described by Stakman et al. (18), were assessed 14 days post inoculation. ITs " 0 ", ";", "1", "2", or combinations thereof were considered low ITs, indicating that the corresponding resistance gene is effective. ITs " 3 " to " 4 " were considered high ITs, indicating that the corresponding resistance gene is not effective against the race tested. In each test, 6 to 10 seedling plants were evaluated and the seedling test was repeated once.

The 103 entries of 1 stSRRSN were also characterized in the seedling growth stage in the greenhouse of CIMMYT, El Batan, Mexico for their resistance to leaf rust with Mexican $P$. triticina races $\mathrm{MBJ} / \mathrm{SP}$ and $\mathrm{MFB} / \mathrm{SP}$ to postulate the presence of genes Lr19 and Lr24 known to be linked to stem rust resistance genes $S r 25$ and $S r 24$, respectively. Race MBJ/SP is avirulent on genes $\operatorname{Lr} 19$ and $L r 24$, whereas MFB/SP is avirulent on $\operatorname{Lr} 19$ but virulent to $\operatorname{Lr} 24$. Ten-day-old seedlings, planted as hills of six to eight seeds, were sprayed with urediniospores suspended in Soltrol 170, incubated in a dew chamber for $16 \mathrm{~h}$, and then placed in a greenhouse maintained at 20 to $23^{\circ} \mathrm{C}$. ITs were recorded about 10 days later using a 0 -to-4 scale for leaf rust similar to that described by Stakman et al. (18).

Application of molecular markers to detect the presence of resistance genes Sr24 and Sr25. All wheat lines were subjected to molecular marker analysis for the presence of $\mathrm{Sr} 24$ and $\mathrm{Sr} 25$ resistance genes using the co-segregating markers $\mathrm{Sr} 24$ no. 12 and STSLr19-130, respectively (14).

Field evaluations for stem rust resistance in Njoro, Kenya. The entries of the 1 stSRRSN were tested in 2005, 2006, and two seasons in 2007 as part of a larger field nursery for stem rust screening in Njoro, Kenya established by the Kenyan Agricultural Research Institute in conjunction with the CIMMYT and the Borlaug Global Rust Initiative.

The nursery site is located at $0^{\circ} 20^{\prime} \mathrm{S}$, $35^{\circ} 56^{\prime} \mathrm{E}$ at $2,185 \mathrm{~m}$ in elevation, with an average daily minimum temperature of $9.7^{\circ} \mathrm{C}$ (night) and an average daily maximum temperature of $23.5^{\circ} \mathrm{C}$ (noon). Variations of average daily temperatures were approximately $\pm 2{ }^{\circ} \mathrm{C}$, occurring mostly during the day hours when evaluations were carried out. Dew was formed nearly daily.

Entries were planted as two 1-m-row plots during 5 to 15 June in all three main seasons and on 20 December in the 2007 off-season. To facilitate inoculum build-up and uniform dissemination within the nursery, a continuous stem rust spreader row (a mixture of susceptible cvs. Chozi and Duma, both carrying Sr31) was planted perpendicular to all entries. The spreader rows were inoculated once by dusting them with a mixture of urediniospores and talc powder. The source of inoculum was a bulk of urediniospores collected from experimental plots of Duma in Kenya.

Plant response to rust infection at the adult plant stage was termed "infection response." Based primarily on the size of pustules and the associated necrosis or chlorosis, infection responses were classified into four discrete categories: $\mathrm{R}=$ resistant, $\mathrm{MR}=$ moderately resistant, $\mathrm{MS}=$ moderately susceptible, and $\mathrm{S}=$ susceptible (13). Infection responses overlapping between any particular two categories were denoted using a dash. For instance, "MRMS" denoted an infection response class that overlapped the MR and MS categories, and was sometimes recorded as $\mathrm{M}$ by some researchers. Stem rust severity was assessed following the modified Cobb scale (8). Entries were evaluated for infection responses and stem rust severity two to three times between heading and plant physiological maturity. The infection responses and stem rust severity at the softdough stage of plant growth (Zadoks scale 8) were used to represent the final disease scores in this report. Due to the close linkage between $\mathrm{Sr} 2$ and pseudo-black chaff
(PBC), scores on PBC were taken to postulate the presence of $\operatorname{Sr} 2$. This was a visual measure scored as present (+) or absent (-). The data was taken at late milk stage in all the four seasons.

\section{RESULTS}

Resistance identified based on seedling ITs. Of the 103 lines tested for seedling IT to Ug99, 71 were resistant, with ITs ranging from 0 ; to $2+$. The genes underlying the resistance were identified as $\mathrm{Sr} 24, \mathrm{Sr} 25$, and other unknown genes based on the stem rust IT data as well as postulations based on reactions to races $\mathrm{MBJ} / \mathrm{SP}$ and MFB/SP of $P$. triticina, the pedigree, and the presence of cosegregating molecular markers. Because genes $\mathrm{Sr} 24$ and $\mathrm{Sr} 25$ are located on alien translocations and inherited together with the leaf rust resistance genes $L r 24$ and Lr19, respectively, they can be detected easily through tests with leaf rust isolates, information on the pedigree, and molecular marker analysis. The leaf rust tests in Mexico and stem rust tests in St Paul, MN using the race TTKSK were in agreement with the presence of co-segregating molecular markers, and the two genes could be postulated without difficulty. Of the 103 lines, 41 had $S r 24$ resistance gene while 18 had Sr25 (Tables 1 and 2). Resistance in 32 lines was due to APR.

The $S r 24$ carrying wheat lines displayed low ITs ranging between $; 2=$ and 12 with $P$. graminis f. sp. tritici race TTKSK (Table 1). With $L r 24$-avirulent $P$. triticina race $\mathrm{MBJ} / \mathrm{SP}$, all these lines displayed ITs 0; or ; similar to the Thatcher tester carrying this gene. However, except for entry no. 6103, all other lines displayed higher ITs ranging between ;1 and 3+ with $L r 24$ virulent race MFB/SP, indicating the presence of $\mathrm{Lr} 24$ and, hence, $\mathrm{Sr} 24$ in these lines. Entry no. 6103 could also carry gene Lr9, which confers IT 0; with the two races used. All lines listed in Table 1 were positive for the molecular marker $\mathrm{Sr} 24$ no. 12 that is diagnostic for $\mathrm{Sr} 24$.

The $S r 25$-carrying wheat lines displayed low ITs ranging between 0 ; and $1+$ with TTKSK and 0 ; with the two $P$. triticina races (Table 2). These lines were positive for the molecular marker STSLr19-130 and, therefore, postulated to carry the $\mathrm{Sr} 25$ gene.

The remaining 12 seedling resistant lines (Table 3) had an unknown genetic basis because they lacked the molecular markers linked to $S r 24$ and $S r 25$, and 11 of these entries did not display low seedling leaf rust ITs. Entry no. 6070 that displayed IT 0 ; with both $P$. triticina races could carry gene $\operatorname{Lr} 9$. Based on the pedigree information, the unknown resistance genes can be postulated to be derived either from Chinese or synthetic wheat backgrounds (Table 3). Two of the lines had resistance based on sources that remain to be identified. Most of the race-specific resistance 
genes, including $\mathrm{Sr} 24$ and $\mathrm{Sr} 25$, were introgressed from alien sources. The unknown genes derived from crosses with $A$. tauschii could be highly valuable new genetic resources for improvement of resistance against race $\mathrm{Ug} 99$.

Thirty-two of the tested lines were susceptible (ITs 3 and 4) at the seedling stage. Such a result is expected for minor genes based on APR (14) and these lines showed from moderate to high levels of resistance at the adult plant stage (Table 4). Twentynine of these lines had a PBC phenotype, a trait linked to the $S r 2$ gene (Table 4). Absence of PBC expression does not exclude the possibility that $S r 2$ is present in the remaining three wheat lines because, in some genetic backgrounds, $\mathrm{PBC}$ remains unexpressed (15).

Resistance identified based on field evaluations. The disease severity was very similar for all the sources of resistance in the first three seasons in Njoro, Kenya (Fig. 1). In the second season of 2007, the disease severity of lines with $\mathrm{Sr} 24$ varied from 15 to $40 \%$ (Fig. 1). This was attributed to the appearance in 2006 of a new mutant race (TTKST) that is virulent for gene $\mathrm{Sr} 24$ but remained in a low frequency. This was confirmed by Jin et al.
(2) from samples collected in 2006 and 2007. Seedling tests indicated that the TTKST variant has a virulence pattern identical to race TTKSK, except that it produced high ITs (IT $2+$ to 3 ) on wheat genotypes that carried $\mathrm{Sr} 24$ (2).

Lines with resistance gene $\mathrm{Sr} 24$ showed a higher level of resistance when this gene occurred together with other sources of resistance like the $1 \mathrm{~A} .1 \mathrm{R}$ chromosomal translocation from rye. Translocation $1 \mathrm{~A} .1 \mathrm{R}$ carries a stem rust resistance gene of unknown relationship to the rye $\mathrm{Sr} 31$ resistance gene and is present in some U.S. winter wheat cultivars such as Amigo,

Table 1. Seedling infection types to Puccinia graminis f. sp. tritici race Ug99 (TTKSK) and P. triticina races MBJ/SP and MFB/SP, field infection responses to race Ug99 for 2005 to 2007 of wheat lines that carry resistance gene $S r 24$, and presence (+) or absence (-) of pseudo-black chaff (PBC) phenotype

\begin{tabular}{|c|c|c|c|c|c|c|c|c|c|}
\hline \multirow[b]{3}{*}{ Entry no. } & \multirow[b]{3}{*}{ Name or cross } & \multicolumn{3}{|c|}{ Seedling infection type ${ }^{a}$} & & & & & \multirow[b]{3}{*}{ PBC } \\
\hline & & \multicolumn{2}{|c|}{ P. triticina } & \multirow{2}{*}{$\begin{array}{c}\text { P. graminis } \\
\text { TTKSK }\end{array}$} & \multicolumn{4}{|c|}{ Year and field rust response ${ }^{b}$} & \\
\hline & & MBJ/SP & MFB/SP & & 2005 & 2006 & 2007-O & 2007-M & \\
\hline 6001 & Krichauff/2*Pastor & ; & $23 c$ & $2-$ & $30 \mathrm{R}$ & $5 \mathrm{RMR}$ & $5 \mathrm{MSS}$ & $40 \mathrm{MSS}$ & + \\
\hline 6002 & Krichauff/2*Pastor & ; & $3+$ & $2-$ & $20 \mathrm{R}$ & 15 RMR & $5 \mathrm{MSS}$ & $30 \mathrm{MSS}$ & + \\
\hline 6003 & Krichauff/2*Pastor & ; & $3+$ & $2-$ & $20 \mathrm{R}$ & $10 \mathrm{RMR}$ & $10 \mathrm{MSS}$ & $10 \mathrm{MSS}$ & + \\
\hline 6004 & Krichauff/2*Pastor & ; & 3 & $2-$ & $20 \mathrm{R}$ & $10 \mathrm{RMR}$ & $15 \mathrm{MSS}$ & $30 \mathrm{MSS}$ & - \\
\hline 6005 & Krichauff/Pastor & & $1+3 c$ & $2-$ & $5 \mathrm{R}$ & $15 \mathrm{M}$ & $10 \mathrm{MSS}$ & $40 \mathrm{MSS}$ & - \\
\hline 6006 & RL6043/4*Nac//2*Pastor & ; & $1+$ & $2=$ & $30 \mathrm{R}$ & $20 \mathrm{RMR}$ & $10 \mathrm{MSS}$ & $15 \mathrm{MSS}$ & + \\
\hline 6007 & Sunco/2*Pastor & 0 & $3+$ & $2-$ & $15 \mathrm{R}$ & $15 \mathrm{RMR}$ & $10 \mathrm{MSS}$ & $10 \mathrm{MSS}$ & + \\
\hline 6008 & Sunco/2*Pastor & ; & $3+$ & $2-$ & $10 \mathrm{R}$ & $30 \mathrm{M}$ & $15 \mathrm{MSS}$ & $40 \mathrm{MSS}$ & + \\
\hline 6009 & Sunco/2*Pastor & ; & $3+$ & $2-$ & $10 \mathrm{R}$ & $30 \mathrm{M}$ & $20 \mathrm{~S}$ & $50 \mathrm{~S}$ & + \\
\hline 6010 & Worrakatta $/ 2 *$ Pastor & ; & $23 c$ & $2-$ & $30 \mathrm{RMR}$ & $30 \mathrm{M}$ & $20 \mathrm{~S}$ & $40 \mathrm{MSS}$ & + \\
\hline 6011 & Worrakatta $/ 2 *$ Pastor & ; & $23 \mathrm{c}$ & $2-$ & $20 \mathrm{R}$ & $20 \mathrm{M}$ & $20 \mathrm{~S}$ & $30 \mathrm{MSS}$ & + \\
\hline 6012 & Worrakatta/ $2 *$ Pastor & 0 & $23 c$ & $2-$ & $20 \mathrm{R}$ & $20 \mathrm{M}$ & $20 \mathrm{~S}$ & $50 \mathrm{MSS}$ & + \\
\hline 6013 & Worrakatta/Pastor & 0 & $23 c$ & 2 & $30 \mathrm{R}$ & $20 \mathrm{M}$ & $10 \mathrm{MSS}$ & $50 \mathrm{MSS}$ & + \\
\hline 6014 & Worrakatta/Pastor & ; & $1+3 c$ & 2 & $5 \mathrm{R}$ & $20 \mathrm{RMR}$ & $5 \mathrm{MSS}$ & $40 \mathrm{MSS}$ & + \\
\hline 6031 & TAM200/Pastor//Tobarito97 & ; & $3+$ & $2-$ & $1 \mathrm{R}$ & $10 \mathrm{R}$ & $10 \mathrm{MSS}$ & $60 \mathrm{~S}$ & - \\
\hline \multirow[t]{2}{*}{6073} & Ald/CEP75630//CEP75234/PT7219/3/Buc/B & & & & & & & & \\
\hline & jy/4/Cbrd/5/Tnmu/PF85487 & 0 & 1 & $2-$ & $10 \mathrm{RMR}$ & $10 \mathrm{R}$ & $10 \mathrm{MSS}$ & $60 \mathrm{M}$ & - \\
\hline \multirow[t]{2}{*}{6074} & Ald/CEP75630//CEP75234/PT7219/3/Buc/B & & & & & & & & \\
\hline & jy/4/Cbrd/5/Tnmu/PF85487 & 0 & 1 & $2-$ & $5 \mathrm{MR}$ & $10 \mathrm{R}$ & $10 \mathrm{MSS}$ & $60 \mathrm{M}$ & - \\
\hline \multirow[t]{2}{*}{6075} & Ald/CEP75630//CEP75234/PT7219/3/Buc/B & & & & & & & & \\
\hline & jy/4/Cbrd/5/Tnmu/PF85487 & 0 & 1 & $2-$ & $5 \mathrm{RMR}$ & $5 \mathrm{R}$ & $10 \mathrm{MSS}$ & $50 \mathrm{M}$ & - \\
\hline 6076 & Babax/LR42//Babax & 0 & 3 & 2 & $5 \mathrm{MR}$ & $30 \mathrm{M}$ & $40 \mathrm{~S}$ & $90 \mathrm{~S}$ & - \\
\hline 6077 & Babax/LR42//Babax & ; & $3+$ & $2-$ & $5 \mathrm{R}$ & $10 \mathrm{MR}$ & $20 \mathrm{MSS}$ & $60 \mathrm{~S}$ & + \\
\hline 6078 & Babax/LR42//Babax/3/Babax/LR42//Babax & ; & $3 c 3$ & $2-$ & $5 \mathrm{R}$ & $10 \mathrm{R}$ & 5 RMR & $40 \mathrm{M}$ & + \\
\hline 6079 & Bow/Gen//Dern/3/Tnmu & 0 & 1 & $2-$ & $5 \mathrm{R}$ & $10 \mathrm{RMR}$ & $10 \mathrm{MSS}$ & $60 \mathrm{~S}$ & - \\
\hline 6081 & Bow/Gen//Dern/3/Tnmu & ; & $; 1$ & $2-$ & $5 \mathrm{R}$ & $10 \mathrm{RMR}$ & $5 \mathrm{MSS}$ & $50 \mathrm{~S}$ & - \\
\hline 6082 & Bow/Gen//Dern/3/Tnmu & ; & $; 1$ & $2-$ & $5 \mathrm{RMR}$ & $10 \mathrm{R}$ & $5 \mathrm{MSS}$ & $60 \mathrm{~S}$ & - \\
\hline 6083 & Bow/Gen//Dern/3/Tnmu & ; & $; 1$ & $2-$ & $5 \mathrm{R}$ & $10 \mathrm{RMR}$ & $5 \mathrm{MSS}$ & $40 \mathrm{MS}$ & - \\
\hline 6084 & Bow/Gen//Dern/3/Tnmu & ; & $; 1$ & $2-$ & $5 \mathrm{R}$ & $10 \mathrm{M}$ & $5 \mathrm{MSS}$ & $40 \mathrm{~S}$ & - \\
\hline \multirow[t]{2}{*}{6085} & CS/Th.cu//Glen/3/Ald/Pvn/4/CS/Le.ra//2*C & & & & & & & & \\
\hline & $\begin{array}{l}\text { S/3/CNO79/5/Sirn//Altar84/Ae.sq. } \\
\text { (205)/3/3*Buc/6/Pastor }\end{array}$ & 0 & $3+$ & $2-$ & $5 \mathrm{R}$ & $10 \mathrm{M}$ & $20 \mathrm{~S}$ & $20 \mathrm{MSS}$ & + \\
\hline 6087 & OR 1 & 0 & 3 & $2-$ & $5 \mathrm{RMR}$ & $10 \mathrm{M}$ & $20 \mathrm{~S}$ & $40 \mathrm{~S}$ & - \\
\hline 6088 & ORL91256 & 0 & $\mathrm{X}$ & $2-$ & 0 & $10 \mathrm{M}$ & $10 \mathrm{MSS}$ & $30 \mathrm{MSS}$ & - \\
\hline 6089 & ORL9127 & ; & 3 & 12 & $5 \mathrm{RMR}$ & $10 \mathrm{M}$ & $20 \mathrm{~S}$ & $40 \mathrm{~S}$ & - \\
\hline 6090 & ORL9127/Pastor//Cbrd & ; & 3 & $2-$ & $10 \mathrm{RMR}$ & $20 \mathrm{M}$ & $10 \mathrm{~S}$ & $40 \mathrm{MS}$ & + \\
\hline 6091 & PBW343/Ducula//PBW343 & 0 & 12 & $; 2=$ & $1 \mathrm{R}$ & $15 \mathrm{M}$ & $10 \mathrm{~S}$ & $40 \mathrm{~S}$ & + \\
\hline 6092 & Thb/Kea//PF85487/3/Milan & ; & 3 & $2=$ & 10 RMR & $10 \mathrm{M}$ & $10 \mathrm{M}$ & $10 \mathrm{MS}$ & - \\
\hline 6093 & Thb/Kea//PF85487/3/Milan & ; & 3 & $2=$ & $10 \mathrm{RMR}$ & $10 \mathrm{M}$ & $10 \mathrm{MSS}$ & $15 \mathrm{M}$ & - \\
\hline 6094 & Thb/Kea//PF85487/3/Rivadeneira4 & ; & 1 & $2-$ & $20 \mathrm{~S}$ & $30 \mathrm{M}$ & $20 \mathrm{~S}$ & $70 \mathrm{~S}$ & + \\
\hline 6095 & Tnmu/3/Ald/Coc//Ures & 0 & 1 & $2-$ & $15 \mathrm{R}$ & $10 \mathrm{M}$ & $15 \mathrm{~S}$ & $40 \mathrm{~S}$ & - \\
\hline 6098 & TAM200/Tui//SW89-5124*2/Fasan & ; & 3 & ;2- & $5 \mathrm{R}$ & $10 \mathrm{M}$ & $10 \mathrm{M}$ & $30 \mathrm{M}$ & + \\
\hline 6099 & TAM200/Tui & 0 & 1 & $2-$ & $15 \mathrm{MR}$ & $10 \mathrm{RMR}$ & $20 \mathrm{RMR}$ & $30 \mathrm{M}$ & + \\
\hline 6101 & TAM200/Tui & 0 & $1+$ & $2-$ & $15 \mathrm{MR}$ & $10 \mathrm{R}$ & $10 \mathrm{RMR}$ & $30 \mathrm{M}$ & + \\
\hline 6102 & TAM200/Tui/3/Babax/LR42//Babax & 0 & $3 c 3$ & $2-$ & $1 \mathrm{R}$ & 15 RMR & $5 \mathrm{R}$ & $20 \mathrm{MS}$ & + \\
\hline 6103 & EMB $16 / \mathrm{Cbrd} / / \mathrm{Cbrd}$ & ; & ; & $2-$ & $5 \mathrm{R}$ & $10 \mathrm{RMR}$ & $5 \mathrm{R}$ & $30 \mathrm{RMR}$ & - \\
\hline Check & PBW343 & $1+3 c$ & 3 & 4 & $100 \mathrm{~S}$ & $90 \mathrm{~S}$ & $100 \mathrm{~S}$ & $100 \mathrm{~S}$ & - \\
\hline
\end{tabular}

a Seedling infection type (IT) for reactions to TTKSK, follow the 0-to-4 scale described in Stakman et al. (18), where ITs 0 , ; , 1, 2, and combinations are resistant reactions and ITs 3 and 4 are susceptible reactions.

${ }^{b}$ Year $2007-\mathrm{O}$ and $2007-\mathrm{M}=$ off-season and main season, respectively. Field response is a combination of disease severity ( 0 to $100 \%$ of the stem rust infection) using the modified Cobb Scale described in Peterson et al. (8) and infection response follow the description of Roelfs et al. (13), where R = resistant, $\mathrm{MR}=$ moderately resistant, $\mathrm{M}=$ moderately resistant to moderately susceptible, $\mathrm{MS}=$ moderately susceptible, and $\mathrm{S}=$ susceptible. 
TAM107, and TAM200 (3). This translocation is also present in a CIMMYT spring wheat line TAM200/TUI (14). On average, a reduction of disease severity was also noted in lines with a combination of $\mathrm{Sr} 24$ and $\operatorname{Sr} 2$ (Table 2). For example, line Krichauff/2*Pastor showed PBC, a phenotypic marker for $\mathrm{Sr} 2$, and scored 10MSS, while the same sib-line without PBC scored 40S. Earlier studies had shown that $\mathrm{Sr} 2$ alone will not confer adequate level of resistance to Ug99 (15). Variation in adult

Table 2. Seedling infection types to Puccinia graminis f. sp. tritici race Ug99 (TTKSK) and $P$. triticina races MBJ/SP and MFB/SP, field infection responses to race Ug99 for 2005-2007 of wheat lines that carry resistance gene $S r 25$, and presence (+) or absence (-) of pseudo-black chaff (PBC) phenotype

\begin{tabular}{|c|c|c|c|c|c|c|c|c|c|}
\hline \multirow[b]{3}{*}{ Entry no. } & \multirow[b]{3}{*}{ Name or cross } & \multicolumn{3}{|c|}{ Seedling infection type ${ }^{a}$} & \multirow{2}{*}{\multicolumn{4}{|c|}{ Year and field rust response ${ }^{b}$}} & \multirow[b]{3}{*}{ PBC } \\
\hline & & \multicolumn{2}{|c|}{ P. triticina } & \multirow{2}{*}{$\frac{\text { P. graminis }}{\text { TTKSK }}$} & & & & & \\
\hline & & MBJ/SP & MFB/SP & & 2005 & 2006 & 2007-O & 2007-M & \\
\hline 6015 & C80.1/3*Batavia//2*Weebill1 & 0 & 0 & 2 & $10 \mathrm{MR}$ & 5 RMR & $5 \mathrm{R}$ & 10 RMR & + \\
\hline 6016 & CMH-81/Hahn//CMH-81/3/Vee/Pjn//2*Tui & 0 & 0 & $2-$ & $5 \mathrm{MR}$ & 5 RMR & $15 \mathrm{M}$ & 10 RMR & + \\
\hline 6017 & CMH-81/Hahn//CMH-81/3/Vee/Pjn//2*Tui & 0 & 0 & $; 2=$ & $30 \mathrm{R}$ & $10 \mathrm{MR}$ & $5 \mathrm{R}$ & 10 RMR & + \\
\hline 6018 & CMH83.2517/Pastor & 0 & 0 & $2-$ & 30 RMR & $20 \mathrm{M}$ & 5 RMR & 15 RMR & - \\
\hline \multirow[t]{2}{*}{6019} & ID\#840335//PIN39/Pew/3/Oasis/4*Bor195/4/ & & & & & & & & \\
\hline & Oasis/5*Bor195 & 0 & 0 & $2-$ & 10 RMR & $5 \mathrm{MR}$ & 5 RMR & $5 \mathrm{R}$ & + \\
\hline 6021 & Kauz*2/Bow//Kauz/3/W98.6.38 & 0 & 0 & $2-$ & $10 \mathrm{M}$ & $10 \mathrm{RMR}$ & $5 \mathrm{R}$ & $5 \mathrm{R}$ & + \\
\hline 6022 & Oasis/SKauz//4*Bcn/3/2*Pastor & 0 & 0 & $2-$ & 15 RMR & 10 RMR & $5 \mathrm{R}$ & 10 RMR & - \\
\hline 6023 & Seri*3//RL6010/4*Yr/3/Pastor & 0 & 0 & $1+$ & $10 \mathrm{M}$ & $10 \mathrm{M}$ & $5 \mathrm{R}$ & 5 RMR & + \\
\hline 6024 & Seri*3//RL6010/4*Yr/3/Pastor/4/Bav92 & 0 & 0 & 2 & $10 \mathrm{M}$ & $10 \mathrm{M}$ & $5 \mathrm{RMR}$ & 15 RMR & + \\
\hline 6025 & Seri*3//RL6010/4*Yr/3/Pastor/4/Bav92 & 0 & 0 & $2-$ & $10 \mathrm{M}$ & $10 \mathrm{RMR}$ & 5 RMR & 10 RMR & + \\
\hline 6026 & Seri*3//RL6010/4*Yr/3/Pastor/4/Pastor & 0 & 0 & 2 & 30 MRMS & $20 \mathrm{RMR}$ & $5 \mathrm{RMR}$ & 10 RMR & + \\
\hline 6027 & SKauz/Bav92 & 0 & 0 & $2-$ & $10 \mathrm{R}$ & $10 \mathrm{MR}$ & $1 \mathrm{R}$ & 5 RMR & + \\
\hline 6028 & SSeri1/Milan & 0 & 0 & $2-$ & 5 RMR & $5 \mathrm{R}$ & $5 \mathrm{R}$ & $5 \mathrm{R}$ & + \\
\hline 6029 & Tukuru/Pastor & 0 & 0 & $2-$ & $5 \mathrm{R}$ & $5 \mathrm{R}$ & $1 \mathrm{R}$ & $5 \mathrm{R}$ & + \\
\hline 6030 & Wheatear & 0 & 0 & $2-$ & $10 \mathrm{RMR}$ & $5 \mathrm{R}$ & $1 \mathrm{R}$ & $5 \mathrm{R}$ & + \\
\hline 6069 & Zhengzhou872//Wizza23/Cona-D/3/Sunsu & 0 & 0 & $2-$ & $10 \mathrm{M}$ & 10 RMR & $5 \mathrm{M}$ & $30 \mathrm{M}$ & - \\
\hline 6096 & Buc/Prl//Weaver/3/Tukuru & 0 & 0 & 0 & 15 RMR & $5 \mathrm{M}$ & $5 \mathrm{R}$ & $10 \mathrm{M}$ & - \\
\hline 6097 & CMH-81/Hahn//CMH-81/3/Vee/Pjn//2*Tui & 0 & 0 & $2-$ & $5 \mathrm{MR}$ & 5 RMR & $5 \mathrm{R}$ & $10 \mathrm{MR}$ & + \\
\hline Check & PBW343 & $1+3 \mathrm{C}$ & 3 & 4 & $100 \mathrm{~S}$ & $90 \mathrm{~S}$ & $100 \mathrm{~S}$ & $100 \mathrm{~S}$ & - \\
\hline
\end{tabular}

a Seedling infection type (IT) for reactions to TTKSK, follow the 0-to-4 scale described in Stakman et al. (18), where ITs 0, ; 1, 2, and combinations are resistant reactions and ITs 3 and 4 are susceptible reactions.

b Year 2007-O and 2007-M = off-season and main season, respectively. Field response is a combination of disease severity (0 to $100 \%$ of the stem rust infection) using the modified Cobb Scale described in Peterson et al. (8) and infection response follow the description of Roelfs et al. (13), where $\mathrm{R}=$ resistant, $\mathrm{MR}=$ moderately resistant, $\mathrm{M}=$ moderately resistant to moderately susceptible, $\mathrm{MS}=$ moderately susceptible, and $\mathrm{S}=$ susceptible.

Table 3. Seedling infection types to Puccinia graminis f. sp. tritici race Ug99 (TTKSK) and P. triticina races MBJ/SP and MFB/SP, field infection responses to race Ug99 for 2005-2007 of wheat lines that carry unknown resistance genes, and presence (+) or absence (-) of pseudo-black chaff (PBC) phenotype

\begin{tabular}{|c|c|c|c|c|c|c|c|c|c|c|}
\hline \multirow[b]{3}{*}{ Entry no. } & \multirow[b]{3}{*}{ Name or cross } & \multicolumn{3}{|c|}{ Seedling infection type ${ }^{a}$} & & & & & \multirow[b]{3}{*}{ PBC } & \multirow[b]{3}{*}{ Source $^{c}$} \\
\hline & & \multicolumn{2}{|c|}{ P. triticina } & \multirow{2}{*}{$\begin{array}{c}\text { P. graminis } \\
\text { TTKSK }\end{array}$} & \multicolumn{4}{|c|}{ Year and field rust response ${ }^{b}$} & & \\
\hline & & MBJ/SP & MFB/SP & & 2005 & 2006 & 2007-O & 2007-M & & \\
\hline 6064 & $\begin{array}{l}\text { Chil/Chuan Mai } \\
\text { 18/4/Buc/Bjy/3/Cndr/Ana// } \\
\text { Cndr/Mus }\end{array}$ & $23 \mathrm{c}$ & $; 1$ & $1+3 \mathrm{C}$ & $30 \mathrm{M}$ & 30 MSS & 20 MSS & $30 \mathrm{M}$ & $\ldots$ & Chuan Mai 18 \\
\hline 6065 & $\begin{array}{l}\text { Kauz//Altar84/Oasis/3/Kauz/4/ } \\
\text { SW94.15464 }\end{array}$ & $3 \mathrm{c}$ & ;123 & $2++$ & 20 RMR & $15 \mathrm{M}$ & $10 \mathrm{R}$ & $30 \mathrm{RMR}$ & + & Durum/Chinese \\
\hline 6066 & $\begin{array}{l}\text { Milan/Shanghai 7/3/Thb/ } \\
\text { CEP7780//Shanghai 4/ } \\
\text { Lira/4/Shanghai 4/Chil }\end{array}$ & $3 c$ & $; 1$ & $2+$ & 20 MRMS & $5 \mathrm{R}$ & $5 \mathrm{R}$ & 10 RMR & - & Chinese \\
\hline 6067 & Ning Mai 50 & $; 12$ & ; & $2++$ & $30 \mathrm{RMR}$ & $40 \mathrm{M}$ & $20 \mathrm{MR}$ & $40 \mathrm{MR}$ & - & Ning Mai 50 \\
\hline 6068 & $\begin{array}{l}\text { Ning Mai 9415.16//Shanghai } \\
\text { 4/Chilero/3/Ning Mai } 50\end{array}$ & $23 \mathrm{c}$ & ; & $2+$ & 30 RMR & $10 \mathrm{M}$ & 5 RMR & 10 RMR & - & Chinese \\
\hline 6070 & $\begin{array}{l}\text { Chen/Ae.sq.//Bcn/3/ } \\
\text { CMH81.38/2*Kauz } \\
\text { Chen/Ae sq//2*Weaver/3/ }\end{array}$ & 0 & 0 & $1+3 \mathrm{C}$ & $5 \mathrm{R}$ & $10 \mathrm{MR}$ & $40 \mathrm{MR}$ & $60 \mathrm{MSS}$ & - & Synthetic \\
\hline 6071 & Oasis/5*Borl95 & $3+$ & 3 & $2+3 \mathrm{C}$ & $10 \mathrm{MSS}$ & $30 \mathrm{M}$ & 5 RMR & $10 \mathrm{MR}$ & & Synthetic \\
\hline $\begin{array}{l}6072 \\
6105\end{array}$ & $\begin{array}{l}\text { Chibia/Dulus } \\
\text { Ning Mai 9558//Chilero/ }\end{array}$ & $1+3 \mathrm{c}$ & ;1- & $2+$ & 30 MRMS & $10 \mathrm{M}$ & 5 RMR & $30 \mathrm{MR}$ & - & Dulus \\
\hline 6106 & $\begin{array}{l}\text { Chuan Mai } 18 \\
\text { Yang87-158*2//Milan/ }\end{array}$ & $1+3 \mathrm{c}$ & ; & $2-$ & $5 \mathrm{R}$ & $5 \mathrm{RMR}$ & 10 RMR & 10 RMR & + & Chinese \\
\hline 6107 & $\begin{array}{l}\text { Shanghai } 7 \\
\text { Croc_1/Ae..sq.(205)//Fct/ }\end{array}$ & 3 & ; & 2 & $30 \mathrm{RMR}$ & $5 \mathrm{RMR}$ & 15 RMR & 20 RMR & + & Shanghai 7 \\
\hline 6108 & $\begin{array}{l}\text { 3/Pastor } \\
\text { Croc_1/Ae.sq.(205)//Fct/ }\end{array}$ & $3+$ & 3 & $2-$ & $10 \mathrm{R}$ & $10 \mathrm{R}$ & $10 \mathrm{R}$ & $5 \mathrm{R}$ & + & Synthetic \\
\hline Check & $\begin{array}{l}\text { 3/Pastor } \\
\text { PBW343 }\end{array}$ & $\begin{array}{l}; 12 \\
1+3 \mathrm{C}\end{array}$ & ; & $\begin{array}{l}2- \\
4\end{array}$ & $\begin{array}{l}15 \mathrm{M} \\
100 \mathrm{~S}\end{array}$ & $\begin{array}{l}20 \mathrm{M} \\
90 \mathrm{~S}\end{array}$ & $\begin{array}{l}5 \mathrm{R}, 40 \mathrm{~S} \\
100 \mathrm{~S}\end{array}$ & $\begin{array}{l}5 \mathrm{RMR} \\
100 \mathrm{~S}\end{array}$ & - & $\begin{array}{l}\text { Synthetic } \\
\ldots\end{array}$ \\
\hline
\end{tabular}

${ }^{a}$ Seedling infection type (IT) for reactions to TTKSK, follow the 0-to-4 scale described in Stakman et al. (18), where ITs 0,; 1,2 , and combinations are resistant reactions and ITs 3 and 4 are susceptible reactions.

b Year 2007-O and 2007-M = off-season and main season, respectively. Field response is a combination of disease severity $(0$ to $100 \%$ of the stem rust infection) using the modified Cobb Scale described in Peterson et al. (8) and infection response follow the description of Roelfs et al. (13), where $\mathrm{R}=$ resistant, $\mathrm{MR}=$ moderately resistant $\mathrm{M}=$ moderately resistant to moderately susceptible, $\mathrm{MS}=$ moderately susceptible, and $\mathrm{S}=$ susceptible.

c Probable source parent. 
plant stem rust severity of lines that carried $\mathrm{Sr} 2$ supports this observation.

Genes Sr24 and Lr24, conferring resistance to stem and leaf rust, respectively, are located on chromosome 3DL on a translocated segment originating from Thinopyron elongatum. There are three distinct Sr24-carrying translocations: the original translocation carried a gene for red grain color, the shorter segment with white grain, and a third segment where a very small segment has been retranslocated onto chromosome 1BS (14). In all three segments, both $S r 24$ and $L r 24$ are present together. Therefore, selection for $L r 24$ with an avirulent leaf rust isolate can be used as an indirect selection strategy for Sr24. The $S r 24$ resistance gene had earlier looked like an attractive candidate for future breeding efforts; however, virulence to Sr24 is known in South Africa and India (14) and the recent detection of the Ug99 mutant race TTKST which is virulent on $\mathrm{Sr} 24$ reduces its usefulness in breeding (2).

Sources with the $S r 25$ gene showed low disease severity across the four seasons and, in fact, very low severity in the 2007 off-season. It was also noted that $\mathrm{Sr} 25$ conferred a high level of resistance only in some genetic backgrounds, especially when the slow rusting APR gene $S r 2$ was also present (e.g., in lines 'Super Seri no. 1 ' [which has yellow flour] and 'Wheatear' [which has white flour]). However, a virulent race was detected in India in 2008 (1) but CIMMYT wheat lines with $\mathrm{Sr} 25$ in the 1stSRRSN remain resistant due to the presence of other unknown resistance genes. The $S r 25$ gene is located on a $T$. elongatum translocation together with leaf rust resistance gene $\operatorname{Lr} 19$ on chromosome 7DL (14). A white-floured mutant of the translocation, developed by D. R. Knott, was transferred into some Australian and CIMMYT wheat backgrounds. Almost all the tested lines with $\mathrm{Sr} 25$ of CIMMYT origin also carried PBC and, hence, $\mathrm{Sr} 2$ (Table 1). Therefore, the combination of $S r 25$ with $S r 2$ may be the reason for low disease severity in these entries. However, due to the major gene effect of $S r 25$, it will be difficult to quantify how much resistance $\mathrm{Sr} 2$ could be contributing. Thus, the $S r 25$ gene could be a good resistance resource but should be used in combination with other effective race- specific resistance genes as well as $\mathrm{Sr} 2$ or other minor genes.

The unknown resistance sources included wheat lines that were derived from crosses with synthetic wheat lines or Chinese wheat genotypes (Table 3). Two of the lines had unknown and not-easy-topredict sources of resistance. The lines with the Chinese parents "Milan/Sha7/ 3/Thb/CEP7780//Sha4/Lira/4/Sha4/Chil", "Ning Mai 9415.16//Sha/4/Chil/3/Ning Mai 50", and "Ning Mai 9558//Chil/Chum18" scored, on average, $10 \%$ severity with an R-MR type of infection response. The gene responsible for the resistance is likely derived from Shanghai no. 7 or Shanghai no. 4 and is tentatively called SrSha7. The CIMMYT parents in the crosses with the Chinese resistant sources are likely to be susceptible to Ug99. Further studies are needed to track the source of resistance in the Chinese wheat parents.

The resistance observed in the synthetic genetic background was due to A. tauschii or Triticum durum parents used in the development of synthetic wheat lines (15). The stem rust severity was between 5 and $10 \%$, with infection responses of $\mathrm{R}$ and

Table 4. Seedling infection types and field infection responses for 2005 to 2007 for wheat lines that carry adult plant resistance genes to race Ug99 (TTKSK) of Puccinia graminis f. sp. tritici and presence (+) or absence (-) of pseudo-black chaff (PBC)

\begin{tabular}{|c|c|c|c|c|c|c|c|}
\hline \multirow[b]{2}{*}{ Entry no. } & \multirow[b]{2}{*}{ Name or cross } & \multirow[b]{2}{*}{$\mathbf{I T}^{\mathbf{b}}$} & \multicolumn{4}{|c|}{ Year and field rust response ${ }^{a}$} & \multirow[b]{2}{*}{ PBC } \\
\hline & & & 2005 & 2006 & 2007-O & 2007-M & \\
\hline 6032 & Babax/3/Oasis/SKauz//4*Bcn/4/Pastor & 4 & 30 MSS & $30 \mathrm{MSS}$ & $40 \mathrm{~S}$ & $10 \mathrm{MSS}$ & + \\
\hline 6033 & Cndo/R143//Ente/Mexi_2/3/Ae.sq,/4/Weaver/5/2*Kauz/6/Fret2 & 4 & 30 MRMS & $20 \mathrm{M}$ & 40 MSS & $30 \mathrm{MSS}$ & + \\
\hline 6034 & Cndo/R143//Ente/Mexi_2/3/Ae.sq./4/Weaver/5/2*Kauz/6/Fret2 & 4 & 30 MRMS & $20 \mathrm{M}$ & 20 MSS & 20 MSS & + \\
\hline 6035 & Dollarbird & 3 & $10 \mathrm{R}$ & $15 \mathrm{M}$ & $15 \mathrm{M}$ & $20 \mathrm{M}$ & + \\
\hline 6036 & Fret $2 * 2 /$ Kukuna & 4 & $30 \mathrm{MS}$ & $20 \mathrm{M}$ & 30 MSS & $30 \mathrm{M}$ & + \\
\hline 6037 & Hartog & $3+$ & $10 \mathrm{MR}$ & $10 \mathrm{M}$ & $10 \mathrm{M}$ & $10 \mathrm{M}$ & + \\
\hline 6038 & He1/3*Cno79//2*Seri/3/Attila/4/WH542 & 3 & $10 \mathrm{R}$ & $50 \mathrm{MSS}$ & 20 MSS & 40 MSS & - \\
\hline 6039 & $\mathrm{Hpo} / \mathrm{Tan} / / \mathrm{Vee} / 3 / 2 * \mathrm{Pgo} / 4 / \mathrm{Milan} / 5 / \mathrm{SS}$ ri 1 & $3+$ & $30 \mathrm{MR}$ & 40 MSS & $30 \mathrm{MSS}$ & $10 \mathrm{MSS}$ & + \\
\hline 6041 & Kamb1*2/Khvaki & $3+$ & $30 \mathrm{MS}$ & $20 \mathrm{M}$ & $15 \mathrm{M}$ & $10 \mathrm{MSS}$ & + \\
\hline 6042 & Kiritati & $3+$ & $10 \mathrm{R}$ & $15 \mathrm{M}$ & $15 \mathrm{M}$ & $10 \mathrm{MS}$ & + \\
\hline 6043 & Parus & 4 & $10 \mathrm{R}$ & $40 \mathrm{~S}$ & $15 \mathrm{M}$ & 20 MSS & + \\
\hline 6044 & Pastor/Milan & $3+$ & $30 \mathrm{M}$ & $15 \mathrm{~S}$ & $15 \mathrm{~S}$ & $5 \mathrm{~S}$ & - \\
\hline 6045 & Pavon F 76 & $3+$ & $10 \mathrm{R}$ & $15 \mathrm{M}$ & $10 \mathrm{M}$ & $5 \mathrm{M}$ & + \\
\hline 6046 & Pfau/Weaver*2//Kiritati & $3+$ & 20 MRMS & $20 \mathrm{M}$ & $10 \mathrm{MS}$ & $5 \mathrm{MS}$ & + \\
\hline 6047 & Pfau/Weaver*2//Kiritati & $3+$ & 20 MRMS & $20 \mathrm{M}$ & $10 \mathrm{MS}$ & 10 MSS & + \\
\hline 6048 & Pfau/Weaver*2//Kiritati & $3+$ & 20 MRMS & $30 \mathrm{M}$ & $10 \mathrm{MSS}$ & $5 \mathrm{MSS}$ & + \\
\hline 6049 & Pfau/Weaver*2//Kiritati & $3+$ & 20 MRMS & $15 \mathrm{M}$ & $5 \mathrm{MS}$ & 5 MSS & + \\
\hline 6050 & Pfau/Weaver*2//Kiritati & $3+$ & 20 MRMS & $10 \mathrm{M}$ & $10 \mathrm{MS}$ & $10 \mathrm{MSS}$ & + \\
\hline 6051 & Pfau/Weaver//Kiritati & $3+$ & 20 MRMS & $10 \mathrm{M}$ & $10 \mathrm{MSS}$ & $5 \mathrm{MSS}$ & + \\
\hline 6052 & Pfau/Weaver//Kiritati & 3 & 20 MRMS & $20 \mathrm{M}$ & $10 \mathrm{MSS}$ & $10 \mathrm{MSS}$ & + \\
\hline 6053 & Pfau/Weaver//Kiritati & $3+$ & 15 MRMS & $10 \mathrm{M}$ & 10 MSS & 10 MSS & + \\
\hline 6054 & Pfau/Weaver//Kiritati & $3+$ & 20 MRMS & $20 \mathrm{M}$ & $20 \mathrm{~S}$ & 40 MSS & + \\
\hline 6055 & Pgo//Croc_1/Ae.sq.(224)/3/2*BorlL95/4/Circus & $3+$ & 10 MRMS & $5 \mathrm{M}$ & 15 MSS & $20 \mathrm{MSS}$ & + \\
\hline 6056 & Pgo//Croc_1/Ae.sq. (224)/3/2*Bor195/4/Circus & 4 & 10 MRMS & $10 \mathrm{M}$ & $10 \mathrm{MSS}$ & $10 \mathrm{MS}$ & + \\
\hline 6057 & Pgo/Seri//Bav92 & $3+$ & $10 \mathrm{R}$ & $15 \mathrm{M}$ & $10 \mathrm{MSS}$ & $10 \mathrm{MSS}$ & + \\
\hline 6058 & Pvn//Car422/Ana/5/Bow/Crow//Buc/Pvn/3/Yr/4/Trap\#1 & $3+$ & $10 \mathrm{R}$ & $30 \mathrm{M}$ & $5 \mathrm{MS}$ & $10 \mathrm{MS}$ & + \\
\hline 6059 & Kingbird & $3+\mathrm{C}$ & 5 MRMS & $5 \mathrm{MR}$ & $5 \mathrm{MSS}$ & 5 MSS & + \\
\hline 6061 & Kingbird & $3+\mathrm{C}$ & 5 MRMS & $5 \mathrm{M}$ & 5 MSS & 5 MSS & + \\
\hline 6062 & Temporalera M 87*2/4/HD2281/Trap\#1/3/Kauz*2/Trap//Kauz & 3 & $30 \mathrm{M}$ & $20 \mathrm{M}$ & $10 \mathrm{M}$ & $30 \mathrm{MSS}$ & - \\
\hline \multirow{2}{*}{6063} & WL6736/5/2*BR12*3/4/IAS55*4/CI14123/3/IAS55*4/ & & & & & & \\
\hline & EG,AUS//IAS55*4/Ald/6/Oasis/5*Borl95/7/Bor195 & $3+$ & 20 MSS & $20 \mathrm{M}$ & $5 \mathrm{MS}$ & 10 MSS & + \\
\hline 6086 & Esda/Lira//Milan/3/Vee\#5/Sara & 3 & $20 \mathrm{~S}$ & $40 \mathrm{~S}$ & $20 \mathrm{~S}$ & 20MSS & + \\
\hline 6104 & Juchi F2000 & 4 & 20 RMR & $20 \mathrm{M}$ & 15 MSS & $30 \mathrm{M}$ & + \\
\hline Check & PBW343 & 4 & $100 \mathrm{~S}$ & $90 \mathrm{~S}$ & $100 \mathrm{~S}$ & $100 \mathrm{~S}$ & - \\
\hline
\end{tabular}

${ }^{a}$ Year 2007-O and 2007-M = off-season and main season, respectively. Field response is a combination of disease severity ( 0 to $100 \%$ of the stem rust infection) using the modified Cobb Scale described in Peterson et al. (8) and infection response follow the description of Roelfs et al. (13), where R = resistant, $\mathrm{MR}=$ moderately resistant, $\mathrm{M}=$ moderately resistant to moderately susceptible, $\mathrm{MS}=$ moderately susceptible, and $\mathrm{S}=$ susceptible.

${ }^{\mathrm{b}}$ Seedling infection type (IT) for reactions to TTKSK, follow the 0-to-4 scale described in Stakman et al. (18), where ITs 0,;, 1, 2, and combinations are resistant reactions and ITs 3 and 4 are susceptible reactions. 
MR. There were some exceptions where the field scores were higher, especially in the main season of 2007 (Table 3). Resistance in synthetic-wheat-derived lines can be due to the presence of $\mathrm{Srl3}$ and $\mathrm{Srl}$ on chromosome $6 \mathrm{AL}$ and $1 \mathrm{BL}$, respectively, originating from durum wheat parents of synthetic wheat lines and Sr33 and a recently designated resistance gene Sr45 on chromosomes 1DL and 2DS, respectively, deriving from $A$. tauschii parents. Genes $S r 13$, Srl4, and Sr33 confer only moderate levels of resistance (4) and they will be useful in areas where stem rust pressure remains at moderate levels. Virulence to both $\operatorname{Srl3}$ and $\mathrm{Sr} 14$ is known among races different from Ug99 (14). Response of $\mathrm{Sr} 45$ with Ug99 in seedling and field conditions is yet to be determined.

Although the disease severity of lines with APR was, on average, higher than that of the lines with other resistance sources (Fig. 1), it maintained a constant infection level (15 to 20\%) throughout the testing period of multiple seasons. Most of the lines in this group scored as low as 5\% severity, on average, with variable infection responses. Kingbird, although susceptible as seedlings in greenhouse tests, was the best line for APR across seasons and maintained very low severity during all seasons. It also carried $\mathrm{Sr} 2$ based on the presence of PBC.
It has been found earlier (6) that $S r 2$ is closely linked to PBC. Of the 32 lines showing APR, almost $90 \%$ had the PBC phenotype, indicating that they carried $\mathrm{Sr} 2$ (Table 4). The slow rusting gene $S r 2$ confers only moderate levels of resistance when present alone. On wheat lines in 1stSRRSN that displayed PBC, we observed varying degrees of disease, with a maximum severity reaching up to $40 \%$ in some seasons compared with $90 \%$ severity for highly susceptible material. Infection responses varying from $\mathrm{MR}$ to $\mathrm{S}$ were scored on the same internodes of $\mathrm{Sr} 2$ carrying plants (Table 4). On several other wheat materials (not included in the 1stSRRSN and data not presented), we also have observed that the level of resistance conferred by $S r 2$ under high disease pressure in Kenya was not sufficient. This indicated that the resistant lines with APR contained other genes, most likely minor, in addition to gene $S r 2$. Genetic analyses of resistance in selected APR wheat cultivars are currently underway to unravel the APR to stem rust.

\section{DISCUSSION}

Based on the seedling ITs as well as field disease severity and infection responses, we identified a number of resistance genes that are effective against Ug99. Although $\mathrm{Sr} 24$ had initially shown a high level of resistance to $\mathrm{Ug} 99$, it was

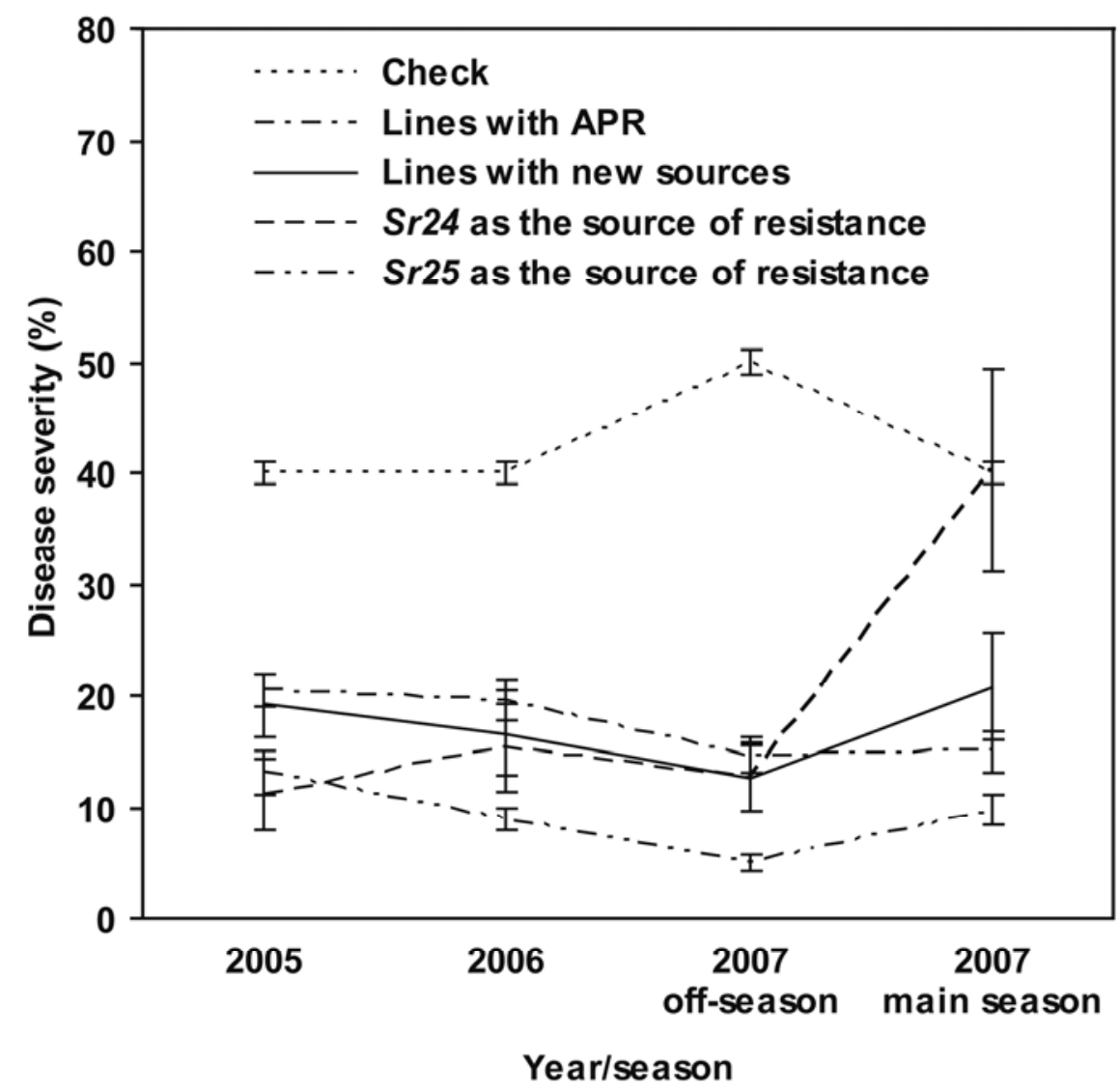

Fig. 1. Average field stem rust severity score (\%) on sources of resistance over four seasons (2005 to 2007) conducted in Njoro, Kenya.

later overcome by the TTKST mutant of Ug99. Sr 24 conferred increased resistance in the presence of the slow rusting APR gene $\mathrm{Sr} 2$. Sr25 showed resistance across the four seasons to $\mathrm{Ug} 99$ and its enhanced expression in CIMMYT germplasm was probably due to the presence of $S r 2$ or other minor genes. The three possibly new sources of resistance from synthetic, Chinese, and other unknown origins represent highly valuable genetic resources in achieving resistance to Ug99. Wheat material with high levels of APR should be used for developing wheat cultivars with durable resistance. The contribution of $\mathrm{Sr} 2$ to APR is obviously highly relevant, given that PBC, a trait associated with $S r 2$, was present in most of the APR wheat lines as well as several of the wheat lines that carried race-specific resistance. We propose to genetically dissect the APR found in these lines to better understand and apply it in breeding for durable stem rust resistance.

\section{LITERATURE CITED}

1. Jain, S. K., Prashar, M., Bhardwaj, S. C., Singh, S. B., and Sharma, Y. P. 2009. Emergence of virulence to Sr25 of Puccinia graminis $\mathrm{f}$. sp. tritici on wheat in India. Plant Dis. 93:840.

2. Jin, Y., Pretorius, Z. A., Singh, R. P., and Fetch, T., Jr. 2008. Detection of virulence to resistance gene $S r 24$ within race TTKS of Puccinia graminis f. sp. tritici. Plant Dis. 92:923-926.

3. Jin, Y., and Singh, R. P. 2006. Resistance in U.S. wheat to recent eastern African isolates of Puccinia graminis f. sp. tritici with virulence to resistance gene Sr31. Plant Dis. 90:476-480.

4. Jin, Y., Singh, R. P., Ward, R. W., Wanyera, R., Kinyua, M. G., Njau, P., Fetch Jr., T., Pretorius, Z. A., and Yahyaoui, A. 2007. Characterization of seedling infection types and adult plant infection responses of monogenic $\mathrm{Sr}$ gene lines to race TTKS of Puccinia graminis f. sp. tritici. Plant Dis. 91:1096-1099.

5. Jin, Y., L. Szabo, M. Rouse, T. Fetch, Jr., Z. A. Pretorius, R. Wanyera, and P. Njau. 2009. Detection of virulence to resistance gene $\mathrm{Sr} 36$ within race TTKS lineage of Puccinia graminis f. sp. tritici. Plant Dis. 93:367-370.

6. Kota, R., Spielmeyer, W., McIntosh, R. A., and Lagudah, E. S. 2005. Fine genetic mapping fails to dissociate durable stem rust resistance gene $\mathrm{Sr} 2$ from pseudo-black chaff in common wheat (Triticum aestivum L.). Theor. Appl. Genet. 112:492-499.

7. McIntosh, R. A. 1988. The role of specific genes in breeding for durable stem rust resistance in wheat and triticale. In: Breeding Strategies for Resistance to the Rust of Wheat. N. W. Simmonds and S. Rajaram, eds. CIMMYT, Mexico, DF.

8. Peterson, R. F., Campbell, A. B., and Hannah, A. E. 1948. A diagrammatic scale for estimating rust severity on leaves and stems of cereals. Can. J. Res. Sect. C. 26:496-500.

9. Pretorius, Z. A., Singh, R. P., Wagoire, W. W., and Payne, T. S. 2000. Detection of virulence to wheat stem rust resistance gene $S r 31$ in Puccinia graminis f. sp. tritici in Uganda. Plant Dis. 84:203.

10. Rajaram, S., Singh, R. P., and Torres, E. 1988. Current CIMMYT approaches in breeding wheat for rust resistance. In: Breeding Strategies for Resistance to the Rust of Wheat. N. W, Simmonds and S. Rajaram, eds. CIMMYT, Mexico, DF.

11. Roelfs, A. P., Long, D. L., and Roberts, J. J. 
1993. Races of Puccinia graminis in the United States during 1990. Plant Dis. 77:125128.

12. Roelfs, A. P., and Martens, J. W. 1988. An international system of nomenclature for Puccinia graminis f. sp. tritici. Phytopathology 78:526-533.

13. Roelfs, A. P., Singh, R. P., and Saari, E. E. 1992. Rust Diseases of Wheat: Concepts and Methods of Disease Management. CIMMYT, Mexico, D.F.

14. Singh, R. P., Hodson, D. P., Huerta-Espino, J. Jin, Y., Njau, P., Wanyera, R., Herrera-Foessel, S. A., and Ward, R. W. 2008. Will stem rust destroy the world's wheat crop? Adv. Agron. 98:271-309.

15. Singh, R. P., Hodson, D. P., Jin, Y., HuertaEspino J., Kinyua, M. G., Wanyera, R., Njau P., and Ward, R. W. 2006. CAB Reviews: Perspectives in Agriculture, Veterinary Science, Nutrition and Natural Resources, 2006, 1, No. 054.

16. Singh, R. P., Huerta-Espino, J., and Rajaram, S. 2000. Achieving near-immunity to leaf and stripe rusts in wheat by combining slow rusting resistance genes. Acta Phytopathol. Entomol. Hung. 35:133-139.

17. Singh, R. P., Jin, Y., Huerta-Espino, J., Njau,
P., and Ward, R. 2007. Progress in the identification and utilization of adult-plant resistance to Puccinia graminis tritici race Ug99 (TTKS) in CIMMYT spring wheats. (Abstr.) Phytopathology 97:S136.

18. Stakman, E. C., Stewart, D. M., and Loegering, W. Q. 1962. Identification of physiologic races of Puccinia graminis var. tritici. U.S Dep. Agric. Agric. Res. Serv. E-617.

19. Wanyera, R., Kinyua, M. G., Jin, Y., and Singh, R. 2005. The spread of stem rust caused by Puccinia graminis f. sp. tritici, with virulence on $\mathrm{Sr} 31$ in wheat in Eastern Africa. Plant Dis. 90:113 